\title{
How the Irish Speak English: A Conversation with T. P. Dolan
}

\author{
by Carolina P. Amador-Moreno \\ University College Dublin
}

Copyright (c) 2007 by Carolina P. Amador-Moreno. This text may be archived and redistributed both in electronic form and in hard copy, provided that the author and journal are properly cited and no fee is charged for access.

Professor T. P. Dolan is a lexicographer and regular contributor to programs on Irish radio and television, who has made the term Hiberno-English widely known in Irish society. He has thus been hugely influential in making the Irish more aware of the features that make their English different from other Englishes. Hiberno-English is nowadays very much a sign of identity for many, a form of English that sets the Irish apart from other native speakers of English. Professor Dolan is also the director of www.hiberno-english.com, which is, as he describes it 'a living museum' or 'living laboratory of HE vocabulary and syntax', where people from all over the world can log questions about the English of Ireland.

T. P. Dolan, profesor, lexicógrafo y colaborador habitual en diferentes programas de radio y televisión, ha conseguido dar a conocer el término "Hiberno-inglés" a una gran parte de la sociedad irlandesa. Gracias a él, en parte, los irlandeses son más conscientes de las características que hacen que el inglés que hablan sea diferente de otras variedades. El hiberno-inglés es en la actualidad un signo de identidad para muchos, una forma de expresión que diferencia a la irlandesa de otras culturas anglo-parlantes. El profesor Dolan dirige también la página web www.hiberno-english.com, 'un museo viviente', o 'un laboratorio de vocabulario y sintaxis hiberno-inglesa', como él mismo lo describe, en el que cualquiera puede enviar preguntas sobre el inglés que se habla en Irlanda.

It is a great pleasure to sit down and talk to someone with whom I share similar research interests. I suppose we should start by defining what Hiberno-English is. What is Hiberno-English? Is it the same as IrE?

Hiberno-English (HE) is the technical term for the Irish use of English. It is a term used, first of all, in the early nineteenth century by the poet Tennyson, and it's been in use ever since then, by very distinguished authors, writers and scholars such as Seamus Heaney (he uses it in his introduction to his great translation of Beowulf). The term Irish English is a misnomer, because it works on the principle that 'Irish English' is similar to Australian English, American English or Canadian English, which it isn’t. English was transported to these countries, but did not mix with the a the native languages. In Ireland, HibernoEnglish means that you have two languages in kind of unruly shotgun marriage together, fighting all the time over the centuries, for syntax, pronunciation, vocabulary, idiom. 'Hiberno-English', therefore, exactly symbolises this very healthy connexion between the two disparate and independent languages.

So, for you, Hiberno-English is more a contact vernacular than a colonial variety of English...

Yes, it is. It's two languages in contact, two languages in equal contact as both have very, very strong backgrounds, both have powerful grammars, and both have very powerful 
literatures as well, so both have the prestige of being independent languages. In other countries, this is not the case. English never had to fight another language.

In comparison with all of those other varieties of English, what is different about the English spoken in Ireland?

First of all, the pronunciation is quite different, because it retains the pronunciation of the English language in its earlier forms, for example, meat is pronounced like mate Very many of the older pronunciations of English are retained in HE, but much more important, we find English consonant and vowels removed and replaced by Irish vowels and consonants, so 'th' in the word thought is often pronounced as [t], thus making it sound like taught. There are many other examples, initial ' $\mathrm{s}$ ' in stairs is sometimes pronounced as 'sh', film is pronounced as fillum. The grammar is particularly different; we say in HE things such as "I'm after having my dinner", "Is it there that you're going?", "He came in and I writing my letter", all of which are based on the grammar of the Irish language. No other form of English has that.

English authors have been rendering the Irish character in plays and novels since the $16^{\text {th }}$ century. They ended up creating a stereotypical figure, which became quite persistent and lasted for a long time. How accurate were these portrayals in linguistic terms?

Well, you are right, there was a stereotypical figure created, known as the Stage Irish person, from the $16^{\text {th }}$ century, in Ben Jonson, and in Shakespeare, then later on in $17^{\text {th }}$ century authors, then, of course with Sheridan later on, and before that with Swift. There is also a stereotypical reference to Irish people in the early $13^{\text {th }}$ century as well, in the poem called The Owl and the Nightingale, and also in Langland's great poem Piers Plowman, and also in the $15^{\text {th }}$ century, an Anglo-Irish writer in this country, called Young, who again gives a stereotypical position of the Irish being semibarbarians. This all had to do with politics, with trying to denigrate the Irish, to prove that they really could not speak English properly, and in that sense, since they could not look after themselves, they had to be dominated. In terms of the accuracy of the portrayals, they were accurate in the sense that they took the most characteristic features of the pronunciation, for instance, and tried to show that these were examples of 'bad English', rather than just the English language converted into the sounds of Irish, so they were accurate, but they were exaggeratedly so.

What about the Irish Literary Revivalists then? They went to the other extreme: Synge, for example fell into an exaggerated portrayal of the Irish. To what extent did he resort to language use? How much damage did that do to people's perceptions of the English spoken in Ireland?

Well, we have to think that Synge was trying to be accurate from a dramatic point of view, and a poetic point of view. He was writing about people who were in the far west of Ireland, who themselves were either Irish speaking or spoke a type of English that was very close to the Irish language, hence, therefore, his use of western English, which is so richly Irish, is his approximation to the way they would speak the Irish language, so in that sense, I don't think he should be castigated at all. He had to compromise and give the impression that they were speaking Irish. He should be celebrated for a brilliant collusion between the two languages. I don't think he did much damage to people's perceptions, because people had those perceptions anyway, all he did was to enrich it, and make it in some ways funny, and in that way, he unwittingly contributed to the transmission of the Stage Irish person.

Joyce's reflection on the word tundish in $A$ Portrait of the Artist... is a wonderful example of philology, and reflects the author's awareness of lexical differences. To what extent are contemporary Irish writers still aware of these differences?

In A Portrait of the Artist...Joyce uses tundish rather than the word funnel, in that way he is showing one of the basic characteristics of HE, which is the retention of older words (Irish people still say press for cupboard, and tundish is still used in Longford to this day, too). He also is good at a phonological level: in that extract from the Portrait, where he refers to the words home, Christ, ale, master, deliberately 
chosen to demonstrate the way Irish people speak English, using the vowels and consonants of Irish (home for example is pronounced [houm] master, for instance would be reproduced with the rhotic ' $r$ '). Contemporary Irish writers, are very much aware of these differences: authors such as Cathy Kelly, Roddy Doyle, Frank MacGuinness, McCabe, and so many others, of course, Seamus Heaney. They are all very accurate. They listen very carefully the way other people speak and convert that by spelling into their plays and novels, so they've much to be praised for.

The work of Seamus Heaney is full of HE. He even translated Beowulf into HE, wasn't there a risk there in terms of the audience? I mean, by deciding to render certain words and phrases into a dialectal form of English, was he not leaving out a wider audience?

I don't think so at all, we must not forget that this book won the Whitbread Book of the Year Prize in 1999, which shows it had a world wide audience, secondly, there is the fact too that the great poem Beowulf itself has a mixture of dialects in it, so by taking Beowulf and turning it into a $\mathrm{HE}$ version, Heaney is exactly capturing the linguistic richness of the original poem. The words he used show the dialectal richness of $\mathrm{HE}$, and demonstrate both the complexion and the complexity of the English language in Northern Ireland, so dialectically it is brilliant.

Moving away from Literature now, what is the attitude of Irish people to HE? Are they nowadays more proud of their English?

Yes, well, young ones, especially, are proud of their English, that's the way they speak it and that's it. Older people are more conscious, very often in all the years we've been interviewing people around the country, older people would hear a London accent such as mine, and they would apologise to me saying: "sorry we cannot speak English as well as you" or "we're bad English speakers" and I say "nonsense, your English is much richer speaker than mine could ever hope to be”.

Do you think that pride among the younger generations is closely related to Ireland's economic development?
Oh, it's entirely related to economic development, because it means they're not depending anymore on going to England for bad jobs, or poorly paid jobs, and that they can get away from the rural background of Ireland as well, which means that young people now have developed a modern form of HE which is entirely new, based on, it must be said, on London English!: they try to measure up to the way they mistakenly think people in the home counties of England speak, they feel that is the style of having made it, of having achieved some economic progress.

\section{So there is still some imperialism..}

Oh, no doubt...imperialism? imperialism is still there, unacknowledged, but still there.

\section{How is HE changing?}

It's changing very much, certainly by what is disappearing. They're getting rid of lots of religious references to the mass, to confession, communion (in the old days, people used to refer to someone who told lies by saying "he'd say mass for you”, but if you say that anymore, people have no idea of what you're talking about). Lots of rural references are going as well, references to horses and heifers, milking sheep, that's all gone, references to tractors are gone (if there's an elderly lady, or gentleman who does not have much chance of marrying they used to say "s/he’s dripping black oil”.

Will HE become so influenced by American English that it will end up losing its flavour? Or will the "Celtic cubs" revert to their roots and the Celtic roots of their language in search for identity?

I think there will be certain changes, because there is a huge influence on Hiberno-English, from American English now (words such as like and so, and whatever, from soap operas, which young people look up to as being stylish). What I think will happen is that this will simply be a rite of passage and eventually the young people will go and revert back to the real roots of their language, in search of, and confirming their identity.

What do you think will be the effect of the new immigrant languages on the English spoken in Ireland nowadays? Will the HE of the future have Polish words? 
I think it's too soon to tell, but if you listen to Polish immigrants and others in the country, you'll find that they're beginning to say "that's grand”, "I'm after doing this”, and we must recognise too that HE has many Eastern European ingredients and it is a perfectly normal thing for languages to absorb languages from other countries.

Tell us a bit about your dictionary. Many of the examples used to illustrate the use of words in it are drawn from literature, isn't that an unrealistic picture of current HE?

The dictionary started way back when I began giving my first lectures on HE. Here, in UCD, we had students from all over the country, and they began to give me examples of words from Donegal, Kerry, Cork and all over. I then decided to write a dictionary and went all over the country for twenty years interviewing people, so the original dictionary was restricted to oral sources. Later on, then, some people said "wouldn't it be nice if you could write a dictionary which would help students of Anglo-Irish literature in Taiwan or Rio de Janeiro?”. So then I attached the literary references to the oral references. That's why most entries, where possible, have both the oral and the literary reference.

But the validity of fictional representation of $\mathrm{HE}$ is something you discuss on your book on MacGill, and that is a very good point. HE literature, as we said earlier in relation to the novels of Roddy Doyle and Cathy Kelly, makes literary references to what is in fact linguistic truth (they do say in this country "I'm after doing this, I'm after doing that" or "He asked was I there" where you have the reverse question), so the literature is simply the second runner to the original runner of the language, which is the oral and so, literature is helpful, but it does not discriminate against the truth of the real value and speech of HE in this country, it incorporates, it doesn't airbrush.

So, one last question that $I$ thought of as we were speaking, what made a Londoner then become interested in HE?

(He laughs) My roots are from Co. Cavan (and I notice he does not pronounce it [kja:van]!). Every year we were taken to County Cavan, where the people there spoke an entirely different language from that I was used to in W3 in London, so I was curious about why they spoke that way, and then when I had the rich opportunity in UCD to teach it, I then noticed there's much more to the story that I had realised and began to research it.

Thank you very much for a most enjoyable conversation.

Thank you.

\section{Works Cited}

Amador Moreno, Carolina P. 2006. The use of Hiberno-English in Patrick MacGill's Early Novels: Bilingualism and Language Shift from Irish to English in County Donegal. Lewiston, New York: The Edwin Mellen Press.

Dolan, Terence Patrick. 2005. A Dictionary of Hiberno-English. Dublin: Gill and Macmillan. First edition 1998.

Heaney, Seamus. 1999. Beowulf: A New Verse Translation. London: Faber. 